\title{
Synthesis of Heterocycles Based on Rhodium-Catalyzed C-H Amination
}

Keisuke Takahashi, Daisuke Yamaguchi, Jun Ishihara, Susumi Hatakeyama*

Graduate School of Biomedical Sciences, Nagasaki University, 1-14 Bunkyo-machi, Nagasaki 852-8521, Japan

Fax +81(95)8192426; E-mail: susumi@nagasaki-u.ac.jp

Received: 26.08.2013; Accepted after revision: 25.09.2013

Abstract: A new stereoselective approach to substituted pyrrolidines and piperidines is described that involves Du Bois' $\mathrm{C}-\mathrm{H}$ amination reaction, Boc-activation of a cyclic sulfamate group, and base-promoted intramolecular cyclization. This methodology can be utilized for the synthesis of tetrahydrofuran and tetrahydrothiophene derivatives.

Key word: C-H amination, heterocycle synthesis, rhodium-catalyzed reaction, cyclization

Developing new methodologies for the synthesis of heterocyclic compounds is of great importance in drug discovery, material science, and natural product synthesis. ${ }^{1,2}$ Recently, we reported the total synthesis of kaitocephalin, ${ }^{3}$ in which we devised a new methodology to construct the highly substituted pyrrolidine core through a rhodiumcatalyzed $\mathrm{C}-\mathrm{H}$ amination ${ }^{4,5}$ followed by an intramolecular nucleophilic attack of a nitrogen atom on a sulfamate group (Scheme 1). Since, to our knowledge, such an approach to heterocyclic compounds has not been reported, ${ }^{6,7}$ we became interested in probing the scope and limitations of this particular pyrrolidine synthesis.

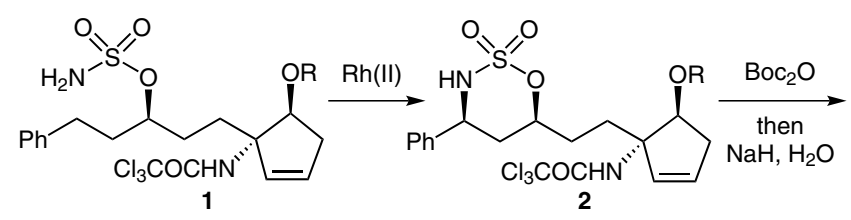

$\mathrm{R}=p-(\mathrm{MeO}) \mathrm{C}_{6} \mathrm{H}_{4} \mathrm{CH}_{2} \mathrm{OCH}_{2}$

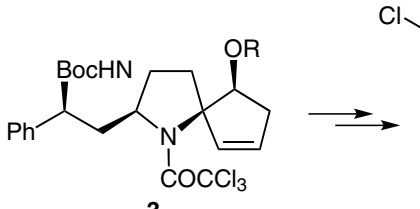

3

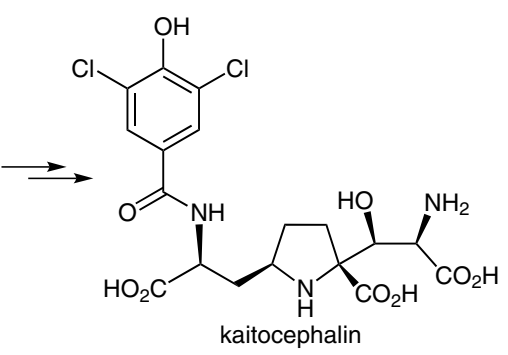

Scheme 1 The key pyrrolidine synthesis

To assess the feasibility of our pyrrolidine synthesis, we first conducted experiments using cyclic $N$-Boc-sulfamate 7a as a substrate, which was prepared from $\mathbf{4}$ via $\mathbf{5}$ and $\mathbf{6 a}$ according to Du Bois' protocol (Scheme 2). ${ }^{4 \mathrm{~b}}$ Initially, the cyclization was examined by using $\mathrm{NaH}$ (2 equiv) in

SYNLETT 2014, 25, 0133-0137

Advanced online publication: 06.11 .2013

DOI: 10.1055/s-0033-1340159; Art ID: ST-2013-U0820-L

(C) Georg Thieme Verlag Stuttgart · New York

tetrahydrofuran (THF) according to the conditions employed for the synthesis of $\mathbf{3}$ (Table 1). In this case, the cyclized compound 8a was not observed on TLC even after ten hours.

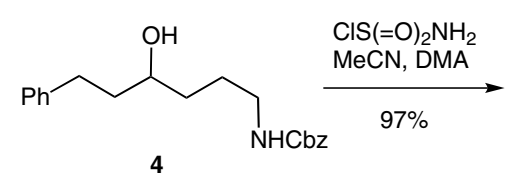

4

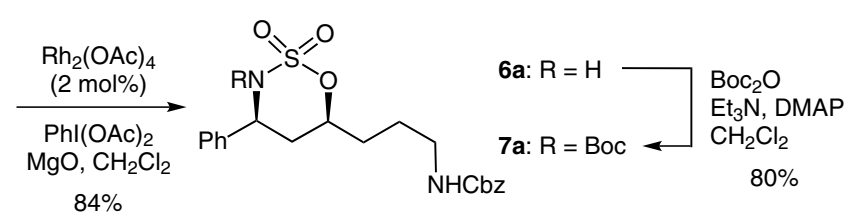

Scheme 2 Preparation of cyclic $N$-Boc-sulfamate $7 \mathbf{a}$

However, when water was added to the mixture, the cyclization occurred instantaneously to give $\mathbf{8 a}$ in $59 \%$ yield (Table 1, entry 1). Interestingly, after treatment of $7 \mathbf{a}$ with $\mathrm{NaH}$ at $0{ }^{\circ} \mathrm{C}$ for $5 \mathrm{~min}$, addition of water (10 equiv) was found to effectively promote the cyclization to afford $\mathbf{8 a}$ in good yield (entry 2). When the reaction was carried out in DMF, 8a was obtained in high yield ${ }^{8}$ and the use of a large excess of water gave comparable results (entries 3 and 4). It turned out that performing the reaction with $3 \mathrm{M}$ $\mathrm{NaOH}$ (2 equiv) in place of $\mathrm{NaH}$ and $\mathrm{H}_{2} \mathrm{O}$ also brought about the cyclization effectively, although the reaction became sluggish (entry 5). However, when a large excess of aqueous $\mathrm{NaOH}$ was used, the yield of $8 \mathbf{a}$ decreased markedly (entry 6). $\mathrm{MeOH}$ could also be employed in place of water (entry 7), although the use of $\mathrm{NaOMe}$ diminished the yield of $\mathbf{8 a}$ (entries 7 and 8). It was also found that no reaction occurred by using $\mathrm{K}_{2} \mathrm{CO}_{3}$ in $\mathrm{MeOH}$ at room tem-

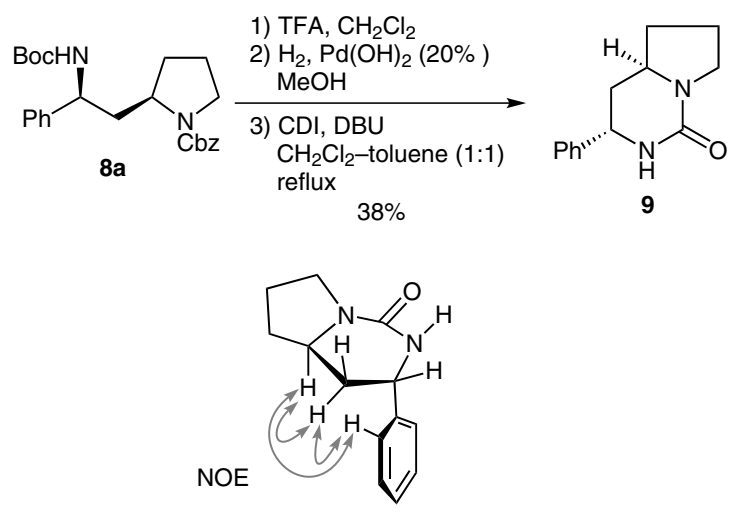

Scheme 3 Confirmation of the stereochemistry of $8 \mathbf{a}$ 
Table 1 Base-Promoted Cyclization of 7a

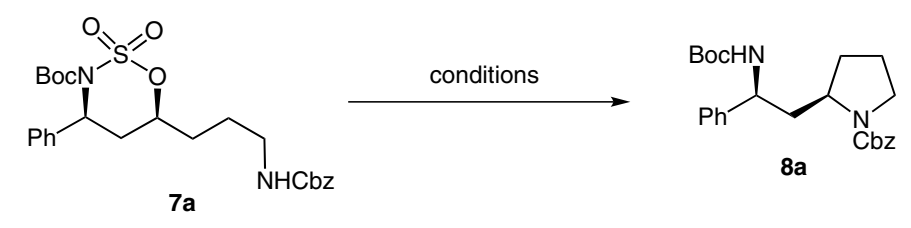

\begin{tabular}{|c|c|c|}
\hline Entry & Conditions & Yield of $8 \mathbf{a}(\%)^{\mathrm{a}}$ \\
\hline 1 & $\mathrm{NaH}$ ( 2 equiv), THF, r.t., $10 \mathrm{~h}$ & $59^{\mathrm{b}}$ \\
\hline 2 & $\mathrm{NaH}$ ( 2 equiv), THF, $0^{\circ} \mathrm{C}, 5 \mathrm{~min}$, add $\mathrm{H}_{2} \mathrm{O}$ ( 10 equiv), then r.t., $30 \mathrm{~min}$ & 78 \\
\hline 3 & $\mathrm{NaH}$ (2 equiv), DMF, $0{ }^{\circ} \mathrm{C}, 5 \mathrm{~min}$, add $\mathrm{H}_{2} \mathrm{O}$ (10 equiv), then r.t., 5 min & 99 \\
\hline 4 & $\mathrm{NaH}$ ( 2 equiv), DMF, $0^{\circ} \mathrm{C}, 5 \mathrm{~min}$, add $\mathrm{H}_{2} \mathrm{O}$ (excess), ${ }^{\mathrm{c}}$ then r.t., 5 min & 92 \\
\hline 5 & $3 \mathrm{M} \mathrm{NaOH}$ (2 equiv), DMF, r.t., $2 \mathrm{~h}$ & 94 \\
\hline 6 & $3 \mathrm{M} \mathrm{NaOH}$ (20 equiv), DMF, r.t., $2 \mathrm{~h}$ & 74 \\
\hline 7 & $\mathrm{NaH}$ ( 2 equiv), DMF, $0{ }^{\circ} \mathrm{C}, 5 \mathrm{~min}$, add $\mathrm{MeOH}$ (10 equiv), then r.t., $5 \mathrm{~min}$ & 84 \\
\hline 8 & $\mathrm{NaOMe}$ ( 2 equiv), $\mathrm{MeOH}$ (20 equiv), DMF, r.t., $10 \mathrm{~h}$ & 55 \\
\hline 9 & $\mathrm{~K}_{2} \mathrm{CO}_{3}$ (2 equiv), $\mathrm{MeOH}$, r.t., $5 \mathrm{~h}$ & no reaction \\
\hline
\end{tabular}

${ }^{\mathrm{a}}$ Isolated yield.

${ }^{\mathrm{b}}$ Before aqueous workup, cyclized compound 8a was not observed on TLC.

${ }^{\mathrm{c}} \mathrm{H}_{2} \mathrm{O}(1 \mathrm{~mL})$ was used for $7 \mathbf{a}(0.21 \mathrm{mmol})$.

perature (entry 9). Although the role of the water is not clear, hydrogen bonding interactions are possibly one of the main factors that influence the reactivity of the process. $^{9}$ The NOESY spectrum of 9 prepared from $\mathbf{8 a}$ confirmed the stereostructure of $\mathbf{8 a}$ (Scheme 3), thus proving that the cyclization took place in an $\mathrm{S}_{\mathrm{N}} 2$ fashion with complete inversion of the stereochemistry.

We next explored the effect of various protecting groups of the primary amine using the optimized $\mathrm{NaH}$ and $\mathrm{H}_{2} \mathrm{O}$ conditions (Table 2). As a result, in addition to $\mathrm{Cbz}$, Moc, and Alloc groups, even the sterically demanding Boc group was found to be suitable for this cyclization (entries

Table 2 Base-Promoted Cyclization of 7a-f

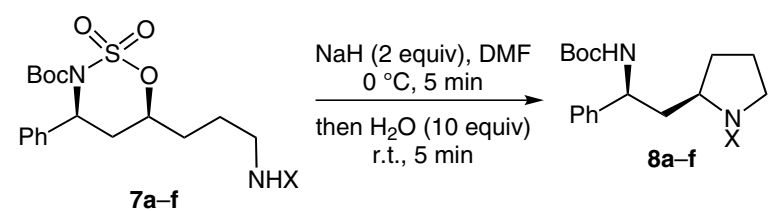

\begin{tabular}{lllll}
\hline \multicolumn{3}{c}{$\mathbf{7 a - f}$} & & \\
Entry & Sulfamate & X & Pyrrolidine & Yield of $8(\%)^{\mathrm{a}}$ \\
\hline 1 & $\mathbf{7 a}$ & Cbz & $\mathbf{8 a}$ & 99 \\
2 & $\mathbf{7 b}$ & Moc & $\mathbf{8 b}$ & 89 \\
3 & $\mathbf{7 c}$ & Alloc & $\mathbf{8 c}$ & 77 \\
4 & $\mathbf{7 d}$ & Boc & $\mathbf{8 d}$ & 75 \\
5 & $\mathbf{7 e}$ & Bz & $\mathbf{8 e}$ & 71 \\
6 & $\mathbf{7 f}$ & Ac & $\mathbf{8 f}$ & 80 \\
\hline
\end{tabular}

${ }^{\text {a }}$ Isolated yield.
1-4). Similarly, benzamide 7e and acetamide $7 \mathbf{f}$ afforded the corresponding cyclized products $8 \mathbf{e}$ and $\mathbf{8 f}$, respectively, in comparable yields (entries 5 and 6).

Based on the optimized reaction conditions, we then evaluated the substrate scope (Table 3). First, five substituted Boc-protected sulfamates $7 \mathbf{g}-\mathbf{k}$ were prepared from $6 \mathbf{g}-\mathbf{k}$ and subjected to cyclization (Method A). It should be stressed that pyrroidines $\mathbf{8 g} \mathbf{- j}$ as well as piperidine $\mathbf{8 k}$ could be synthesized in moderate overall yields regardless of the substitution pattern, even in the case where a quaternary center is present near the reaction site (entries 25). Next, step-economical one-pot preparation ${ }^{10}$ of $8 \mathbf{a}$ and $\mathbf{8 f}-\mathbf{k}$ from $\mathbf{6 a}$ and $\mathbf{6 f}-\mathbf{k}$ was also investigated (Method B). ${ }^{11}$ Thus, after confirming the formation of $\mathbf{7 a}$ and $7 \mathbf{g}-\mathbf{k}$ on TLC, their cyclizations were conducted by adding $\mathrm{NaH}$ ( 3 equiv) followed by water (10 equiv). We were pleased to find that this one-pot procedure worked effectively and, except for $\mathbf{8 i}$, afforded the corresponding

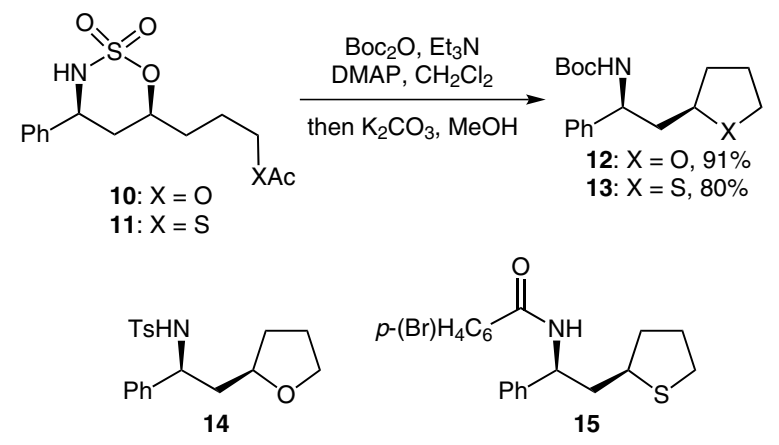

Scheme 4 Synthesis of tetrahydrofuran $\mathbf{1 2}$ and tetrahydrothiophene 13 
cyclized products in good yields. In the case of $\mathbf{6 i}$, butoxycarbonylation did not proceed selectively on the sulfamate nitrogen and the reaction produced several Boc-protected products.

We also examined the synthesis of tetrahydrofuran $\mathbf{1 2}$ and tetrahydrothiophene $\mathbf{1 3}$ from $\mathbf{1 0}$ and 11, based on the methodology detailed above (Scheme 4). As a result, a one-pot procedure involving butoxycarbonylation of a sulfamate and methanolytic removal of the acetyl group turned out to be operative in these cases, and the cyclized compounds 12 and 13, respectively, were obtained in good yields. The stereochemistries of $\mathbf{1 2}$ and $\mathbf{1 3}$ were un-

Table 3 Synthesis of $\mathbf{8 a}, \mathbf{g}-\mathbf{k}$

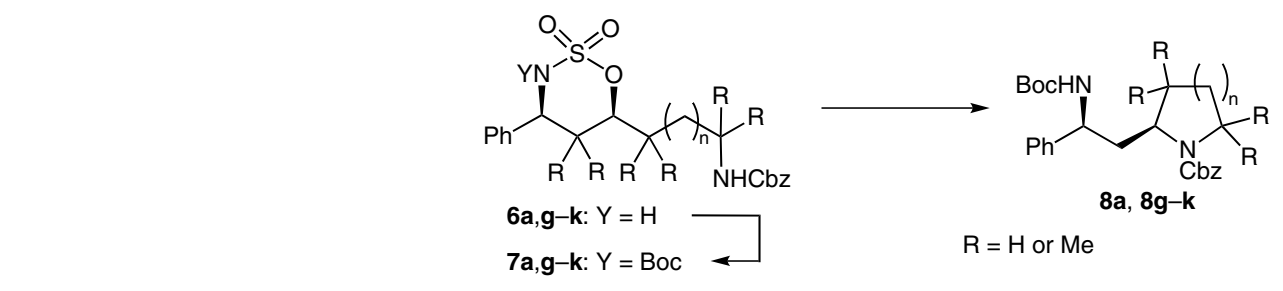

\begin{tabular}{|c|c|c|c|c|}
\hline Entry & Sulfamate & Yield of $7(\%)^{\mathrm{a}}$ & Product & Yield of $8(\%)^{a}$ \\
\hline
\end{tabular}

1<smiles>O=C(NCCCC1CC(c2ccccc2)N(C(=O)O)C(=O)O1)OCc1ccccc1</smiles>

80<smiles>CC(C)(C)OC(CC1CCCN1Cc1ccccc1)c1ccccc1</smiles>

$8 \mathbf{a}$

$7 \mathbf{a}$<smiles>CC(=O)NCC[C@H](C)[C@H]1CC(c2ccccc2)N(C(=O)OCc2ccccc2)S(=O)(=O)O1</smiles>

$7 \mathrm{~g}$<smiles>CC(C)(C)OCCCC(C)(C)C1CC(c2ccccc2)N(C(=O)c2ccccc2)S(=O)(=O)O1</smiles>

$7 \mathrm{~h}$<smiles>CC(=O)NCCCC1OS(=O)(=O)N(C(=O)c2ccccc2)C(c2ccccc2)C1(C)C</smiles>

$7 \mathbf{i}$<smiles>CC(C)(CCC1CC(c2ccccc2)NS(=O)(=O)O1)NC(=O)OCc1ccccc1</smiles>

$7 \mathbf{j}$<smiles>O=C(NCCCC[C@@H]1CC(c2ccccc2)[C@@H](C(=O)c2ccccc2)S(=O)(=O)O1)c1ccccc1</smiles>

8k
80<smiles>CC1CCN(CC(N)c2ccccc2)C1CC(N)c1ccccc1</smiles>

$8 \mathrm{~g}$<smiles>CC(C)(C)OC(=O)c1ccccc1CC1NCCC1(C)C</smiles>

$79^{\mathrm{b}}(77)^{\mathrm{c}}$

$8 h$<smiles>CC(C)(C)OC(=O)C(c1ccccc1)C(C)(C)[C@H]1CCCN1[O+]</smiles>
$74^{\mathrm{b}}(\text { complex mixture })^{\mathrm{c}}$

$8 \mathbf{i}$<smiles>CC1(C)CCC(CC(NC(=O)c2ccccc2)c2ccccc2)N1O</smiles>

$88^{\mathrm{b}}(77)^{\mathrm{c}}$

8j<smiles>CON1CCCCC1Cc1ccccc1C(N)OC(C)(C)C</smiles>

$85^{\mathrm{b}}(80)^{\mathrm{c}}$

$7 k$

\footnotetext{
${ }^{a}$ Isolated yield.

${ }^{b}$ Method A: (1) $\mathrm{Boc}_{2} \mathrm{O}, \mathrm{Et}_{3} \mathrm{~N}-\mathrm{DMAP}, \mathrm{CH}_{2} \mathrm{Cl}_{2}$; (2) $\mathrm{NaH}$ (2 equiv), DMF, $0{ }^{\circ} \mathrm{C}, 5$ min, then $\mathrm{H}_{2} \mathrm{O}$ (10 equiv), r.t., 5 min.

${ }^{\mathrm{c}}$ Method B (one-pot): $\mathrm{Boc}_{2} \mathrm{O}, \mathrm{Et}_{3} \mathrm{~N}-\mathrm{DMAP}$, DMF, then $\mathrm{NaH}$ (3 equiv), $0{ }^{\circ} \mathrm{C}, 5 \mathrm{~min}$, then $\mathrm{H}_{2} \mathrm{O}$ (10 equiv), r.t., 5 min.
} 
ambiguously determined by X-ray crystallographic analysis of their derivatives $14^{12}$ and $\mathbf{1 5} .^{13}$

In conclusion, the present work provides a new methodology for the stereoselective construction of substituted heterocycles such as pyrrolidines, piperidines, tetrahydrofurans, and tetrahydrothiophenes utilizing rhodium-catalyzed $\mathrm{C}-\mathrm{H}$ amination.

\section{Acknowledgment}

This work was supported by a Grant-in-Aid for Scientific Research (A) (22249001) and a Grant-in-Aid for Young Scientists (B) (23790015) from JSPS, a Grant-in-Aid for Scientific Research on Innovative Areas 'Reaction Integration' (No. 2105) (22106538 and 24106736) from MEXT and The Naito Foundation.

Supporting Information for this article is available online at http://www.thieme-connect.com/ejournals/toc/synlett.

\section{References and Notes}

(1) For recent reviews, see: (a) Mihovilovic, M. D.; Stanetty, P. Angew. Chem. Int. Ed. 2007, 46, 3612. (b) Godoi, B.; Schumacher, R. F.; Zeni, G. Chem. Rev. 2011, 111, 2937. (c) Eckert, H. Molecules 2012, 17, 1074. (d) Foster, R. A. A.; Willis, M. C. Chem. Soc. Rev. 2013, 42, 63. (e) Dubrovskiy, A. V.; Markina, N. A.; Larock, R. C. Org. Biomol. Chem. 2013, 11, 191. (f) Zhang, M.; Zhang, A.-Q.; Peng, Y. J. Organomet. Chem. 2013, 723, 224. (g) Ball, C. J.; Willis, M. C. Eur. J. Org. Chem. 2013, 425.

(2) For methodologies for heterocycle synthesis recently developed by our group, see: (a) Takahashi, K.; Haraguchi, N.; Ishihara, J.; Hatakeyama, S. Synlett 2008, 671.

(b) Takahashi, K.; Midori, M.; Kawano, K.; Ishihara, J.; Hatakeyama, S. Angew. Chem. Int. Ed. 2008, 47, 6244.

(c) Hatakeyama, S. Pure Appl. Chem. 2009, 81, 217.

(d) Takahashi, K.; Hatakeyama, S. J. Synth. Org. Chem., Jpn. 2010, 68, 951. (e) Eto, K.; Yoshino, M.; Takahashi, K.; Ishihara, J.; Hatakeyama, S. Org. Lett. 2011, 13, 5398. (f) Sarkar, S. M.; Taira, Y.; Nakano, A.; Takahashi, K.; Ishihara, J.; Hatakeyama, S. Tetrahedron Lett. 2011, 52, 923.

(3) Takahashi, K.; Yamaguchi, D.; Ishihara, J.; Hatakeyama, S. Org. Lett. 2012, 14, 1644.

(4) (a) Espino, C. G.; Du Bois, J. Angew. Chem. Int. Ed. 2001, 40, 598. (b) Espino, C. G.; Wehn, P. M.; Chow, J.; Du Bois, J. J. Am. Chem. Soc. 2001, 123, 6935. (c) Espino, C. G.; Fiori, K. W.; Kim, M.; Du Bois, J. J. Am. Chem. Soc. 2004, 126, 15378. (d) Fiori, K. W.; Du Bois, J. J. Am. Chem. Soc. 2007, 129, 562. (e) Zalatan, D. N.; Du Bois, J. J. Am. Chem. Soc. 2009, 131, 7558.

(5) For reviews, see: (a) Zalatan, D. N.; Du Bois, J. Top. Curr. Chem. 2010, 292, 347. (b) Du Bois, J. Org. Process Res. Dev. 2011, 15, 758.

(6) For a review on $\mathrm{C}-\mathrm{H}$ bond functionalization, see: Yamaguchi, J.; Yamaguchi, A. D.; Itami, K. Angew. Chem. Int. Ed. 2012, 51, 8960.

(7) For heterocycle syntheses utilizing Rh-catalyzed $\mathrm{C}-\mathrm{H}$ amination, see: (a) Wehn, P. M.; Du Bois, J. J. Am. Chem. Soc. 2002, 124, 12950. (b) Hinman, A.; Du Bois, J. J. Am. Chem. Soc. 2003, 125, 11510. (c) Fleming, J. J.; Du Bois, J. J. Am. Chem. Soc. 2006, 128,3926 . (d) Conrad, R. M.; Du Bois, J. Org. Lett. 2007, 9, 5465. (e) Yakura, T.; Yoshimoto, Y.; Ishida, C.; Mabüchi, S. Tetrahedron 2007, 63, 4429. (f) Narina, S. V.; Kumer, T. S.; George, S.; Sudalai, A. Tetrahedron Lett. 2007, 48, 65. (g) Yakura, T.; Sato, S.; Yoshimoto, Y. Chem. Pharm. Bull. 2007, 55, 1284.

(h) Kang, S.; Lee, H.-K. J. Org. Chem. 2010, 75, 237.

(i) Tanino, T.; Ichikawa, S.; Shiro, M.; Matsuda, A. J. Org. Chem. 2010, 75, 1366. (j) Tanino, T.; Ichikawa, S.; Matsuda, A. Org. Lett. 2011, 13, 4028.

(8) Preparation of 8a from 4 via 5, 6a, and 7a; Sulfamate 5: Formic acid $(0.69 \mathrm{~mL}, 15 \mathrm{mmol})$ was added to neat chlorosulfonyl isocyanate $(1.3 \mathrm{~mL}, 15 \mathrm{mmol})$ at $0{ }^{\circ} \mathrm{C}$ and the mixture was stirred for $5 \mathrm{~min}$. $\mathrm{MeCN}(10 \mathrm{~mL})$ was added and the mixture was stirred at r.t. for $8 \mathrm{~h}$ to generate sulfamoyl chloride (1.5 M in MeCN). To an ice-cooled solution of $\mathbf{4}$ $(1.40 \mathrm{~g}, 4.28 \mathrm{mmol})$ in DMA $(10 \mathrm{~mL})$ and $\mathrm{MeCN}(10 \mathrm{~mL})$ was added sulfamoyl chloride (1.5 M in MeCN, $5.7 \mathrm{~mL}, 8.56$ $\mathrm{mmol})$. The mixture was stirred at r.t. for $1 \mathrm{~h}$ and saturated $\mathrm{NaHCO}_{3}(5 \mathrm{~mL})$ was added at $0{ }^{\circ} \mathrm{C}$. The mixture was extracted with EtOAc, washed with brine, dried over $\mathrm{MgSO}_{4}$, and concentrated in vacuo. Purification of the residue by column chromatography $\left(\mathrm{SiO}_{2} 30 \mathrm{~g}\right.$; hexaneEtOAc, 4:1 to $1: 1)$ gave $5(1.70 \mathrm{~g}, 97 \%)$ as a colorless amorphous solid.

Cyclic Sulfamate 6a: To a solution of $5(411 \mathrm{mg}, 1.08$ $\mathrm{mmol})$ in $\mathrm{CH}_{2} \mathrm{Cl}_{2}(10 \mathrm{~mL})$ at r.t. were added $\mathrm{MgO}(100 \mathrm{mg}$, $2.50 \mathrm{mmol}), \mathrm{PhI}(\mathrm{OAc})_{2}$ (BAIB; $354 \mathrm{mg}, 1.12 \mathrm{mmol}$ ), and $\mathrm{Rh}_{2}(\mathrm{OAc})_{4}(9 \mathrm{mg}, 0.02 \mathrm{mmol})$. After stirring at r.t. for $2 \mathrm{~h}$, the mixture was filtered through cotton and concentrated in vacuo. Purification of the residue by column chromatography $\left(\mathrm{SiO}_{2} 30 \mathrm{~g}\right.$; hexane-EtOAc, 3.5:1 to 1.5:1) gave 6 a $(371 \mathrm{mg}, 84 \%)$ as a colorless amorphous solid. $N$-Boc Sulfamate 7a: To a stirred solution of $6 \mathbf{a}(1.10 \mathrm{~g}$, $0.75 \mathrm{~mol})$ in $\mathrm{CH}_{2} \mathrm{Cl}_{2}(20 \mathrm{~mL})$ at r.t. were added $\mathrm{Et}_{3} \mathrm{~N}(0.59$ $\mathrm{mL}, 4.08 \mathrm{mmol})$, Boc $2 \mathrm{O}(712 \mathrm{mg}, 0.98 \mathrm{mmol}$ ), and DMAP $(33 \mathrm{mg}, 0.27 \mathrm{mmol}$ ). After stirring at r.t. for $5 \mathrm{~h}$, the mixture was extracted with EtOAc, washed with brine, dried over $\mathrm{MgSO}_{4}$, and concentrated in vacuo. Purification of the residue by column chromatography $\left(\mathrm{SiO}_{2} 15 \mathrm{~g}\right.$; hexaneEtOAc, $4: 1)$ gave $7 \mathbf{a}(1.10 \mathrm{~g}, 80 \%)$ as a colorless amorphous solid.

Pyrrolidine 8a: To an ice-cooled solution of 7a $(100 \mathrm{mg}$, $0.20 \mathrm{mmol})$ in DMF $(2 \mathrm{~mL})$ was added $\mathrm{NaH}(60 \%$ in mineral oil, $16 \mathrm{mg}, 0.40 \mathrm{mmol})$. The mixture was stirred at $0{ }^{\circ} \mathrm{C}$ for $5 \mathrm{~min}$, then $\mathrm{H}_{2} \mathrm{O}(36 \mu \mathrm{L}, 2.0 \mathrm{mmol})$ was added and the mixture was stirred at r.t. for $5 \mathrm{~min}$. The mixture was neutralized with $1 \mathrm{M} \mathrm{HCl}$, extracted with EtOAc, washed with sat. $\mathrm{NaHCO}_{3}$ and brine, dried over $\mathrm{MgSO}_{4}$, and concentrated in vacuo. Purification of the residue by column chromatography $\left(\mathrm{SiO}_{2} 5 \mathrm{~g}\right.$; hexane-EtOAc, 5:1) gave 8a (83 $\mathrm{mg}, 99 \%$ ) as a colorless solid.

(9) For related water-promoted displacement reactions, see: (a) Azizi, N.; Saidi, M. R. Org. Lett. 2005, 7, 3649.

(b) Vilotijevic, I.; Jamison, T. F. Science 2007, 317, 1189. (c) Wang, Z.; Cui, Y.-T.; Xu, Z.-B.; Qu, J. J. Org. Chem. 2008, 73, 2270. (d) Tanaka, Y.; Fuse, S.; Tanaka, H.; Doi, T.; Takahashi, T. Org. Process Res. Dev. 2009, 13, 1111. (e) Shimokawa, J.; Harada, T.; Yokoshima, S.; Fukuyama, T. J. Am. Chem. Soc. 2011, 133, 17634.

(10) (a) Suga, S.; Yamada, D.; Yoshida, J. Chem. Lett. 2010, 39, 404. (b) Yoshida, J.; Saito, K.; Nokami, T.; Nagaki, A. Synlett 2011, 1189.

(11) Representative One-Pot Preparation (Method B): $\mathrm{Et}_{3} \mathrm{~N}$ $(0.05 \mathrm{~mL}, 0.38 \mathrm{mmol})$, DMAP ( $3 \mathrm{mg}, 0.025 \mathrm{mmol})$, and $\mathrm{Boc}_{2} \mathrm{O}(72 \mathrm{mg}, 0.33 \mathrm{mmol})$ were added to a solution of $6 \mathbf{a}$ $(100 \mathrm{mg}, 0.25 \mathrm{~mol})$ in DMF $(2 \mathrm{~mL})$ at r.t. The mixture was stirred at r.t. for $5 \mathrm{~h}$, then $\mathrm{NaH}(60 \%$ in mineral oil, $30 \mathrm{mg}$, $0.75 \mathrm{mmol}$ ) was added at $0{ }^{\circ} \mathrm{C}$. The mixture was stirred at $0{ }^{\circ} \mathrm{C}$ for $5 \mathrm{~min}$, then $\mathrm{H}_{2} \mathrm{O}(45 \mu \mathrm{L}, 2.5 \mathrm{mmol})$ was added, and 
the mixture was stirred at r.t. for $5 \mathrm{~min}$. The mixture was neutralized with $1 \mathrm{M} \mathrm{HCl}$, extracted with EtOAc, washed with saturated $\mathrm{NaHCO}_{3}$ and brine, dried over $\mathrm{MgSO}_{4}$, and concentrated in vacuo. Purification of the residue by column chromatography $\left(\mathrm{SiO}_{2} 5 \mathrm{~g}\right.$; hexane-EtOAc, 5:1) gave 8a (85 $\mathrm{mg}, 81 \%$ ) as a colorless solid.
(12) The crystallographic data (CCDC 943270) can be obtained free of charge from the Cambridge Crystallographic Data centre via www.ccdc.cam.ac.uk/data request/cif.

(13) The crystallographic data (CCDC 943271) can be obtained free of charge from the Cambridge Crystallographic Data centre via www.ccdc.cam.ac.uk/data_request/cif. 